\title{
THE ROLE OF PROSECUTOR OFFICE IN THE ERADICATION OF CORRUPTION CRIMINAL ACTS IN INDONESIA
}

\author{
Sri Endah Wahyuningsih \\ endah.w@unissula.ac.id \\ Faculty of Law, Sultan Agung Islamic University, Semarang \\ Agus Sunaryo \\ agussunaryo@yahoo.com \\ Faculty of Law of Sultan Agung Islamic University
}

\begin{abstract}
In fact, there are still many cases of corruption that have not been revealed; this resulted in the public to be pessimistic with the seriousness of the Prosecutor Office in uncovering various cases of corruption that are happening today. The purpose of this study is to know the role of the Prosecutor Office in the eradication of criminal acts, to obtain an overview of the mechanism of corruption handling by prosecutors in Indonesia and to analyze the obstacles and solutions in eradicating crime in the Attorney General. The research method was sociological juridical, and data collection were gained by using observation and interview. The existence and role of the Public Prosecution Service in eradicating corruption crime begins when the case has not been transferred to the Court until the execution of the decision of the Court. However, in the criminal act of corruption the Prosecutor's Office has the authority as a public prosecutor as well as an investigator. The authority of the prosecutor as a special criminal investigator shall be regulated by Law Number 16 Year 2004 regarding the Attorney of the Republic of Indonesia in Article 30 paragraph (1) letter $d$. In addition, in its role against the eradication of corruption, the Prosecutor's Office has always conducted a coordination relationship with the Police Agency and the Corruption Eradication Commission. The mechanism for handling corruption in the Attorney General Office, through several procedures already set out in the law includes Investigation, Investigation and Prosecution.
\end{abstract}

Keywords: Role of Attorney, Crime, Corruption, Indonesia

\section{A. INTRODUCTION}

The current time, corruption crime becomes a conversation that is always discussed in many forums, and becomes the main case that is noticed by the state or by the authorities. The Prosecutor Office is one of the legal instruments that is entitled to handle corruption cases in Indonesia, where the prosecutor is required to work with the eradication of corruption.

The problem of corruption is no longer a new problem in the legal and economic matters of a country, since corruption has existed thousands of years ago, both in developed and developing countries as well as in Indonesia today. Corruption has been regarded by society as the most dangerous problem in Indonesia. In fact, the development of corruption problems in Indonesia today is already so severe and a very extraordinary problem because it has spread and spread to all levels of society. ${ }^{1}$

Corruption has occurred in many areas in the development process, because along with the rapid development, it is also increasing the leakage of funds of development, it is evidenced in the case of corruption billions of rupiah. The development of the corruption problem in Indonesia is severe and it is recommended that a firm action, so that it fears the corruptor. ${ }^{2}$ Corruption has become a crime, it is considered to have damaged the joints of social life and the state.

\footnotetext{
Edy Yunara, Korupsi dan Pertanggungjawaban Pidana Korupsi, Citra Aditya Bakti, Bandung, 2005, Page. 1

2 Andi Hamzah, Korupsi di Indonesia Masalah dan Pemecahannya, Gramedia Pustaka Utama, Jakarta, 2003, Page. 4
} 
State losses caused by corruption have been categorized as "harmful". ${ }^{3}$

Corruption in Indonesia is an issue of a recurrent or very urgent that has faced the Indonesian nation today, from time to time in a relatively long span of time. Thus, a special court of corruption is expected to resolve a number of past corruption crimes in order to reciprocate the losses of the state has been taken by the perpetrators of criminal acts.

Furthermore, one of the reasons for the failure of law enforcement against "rampant corruption" is the absence of consensus on what is a criminal act worthy of crime. Mardjono Reksodiputro explains some approaches that might explain why there is no such consensus. The first approach sees criminal law as a source of social order that serves to resolve and prevent conflict. Law is seen as the result of consensus. Enforcement aims to maintain consensus. The second approach considers criminal law as a "tool" in social conflict, and is primarily used to defend the power or privileges of the group that holds power over other groups. Law is seen as the result of conflict between different groups of different interests. ${ }^{4}$

Corruption has been rampant in all dimensions of the nation's life cannot be denied ${ }^{5}$. According to economist Kwik Kian Gie as quoted by Yudi Kristina, once gave a picture of how much corrupt country wealth (per year), which mentioned exceeds the state budget ${ }^{6}$ (APBN). Recognizing the complexity of corruption in the midst of multidimensional crises and the imminent real threat, the impact of these crimes, corruption can be categorized as a national problem that must be dealt with thoroughly through a clear and firm involving all the potential that exists

3 Efi Laila Kholis, Pembayaran Uang Pengganti dalam Perkara Korupsi, Solusi Publishing, Jakarta, 2010, Page. 5

4 Mardjono Reksodiputro, Korupsi dalam Sistem Hukum. Mencari Uang Rakyta: 16 Kajian Korupsi di Indonesia. Ed. Hamid Basyaib, Richard Holloway, dan Nono Anwar Makarim. Aksara Foundation, Jakarta, 2002, Page. 27

5 IGM Nurdjana, Korupsi dalam Praktik: Bisnis Pemberdayaan Penegakan Hukum, Program aksi dan Strategi Penanggulangan Masalah Korupsi, Gramedia Pustaka Utama, Jakarta, 2005, Page. 1

6 Yudi Kristina, Menuju Progresif, LSHP, Yogyakarta, 2009, Page. 1 in society, especially the government and law enforcement. $^{7}$

Law enforcers who are involved in the eradication of corruption are investigators, prosecutors and judges. The final determinant in the eradication of corruption is the judge. However, the judge cannot act actively outside the context of the case brought to trial by the prosecutor (prosecutor). The actor who actively conducts investigations and prosecution is the prosecutor. Therefore, it is not excessive if until now the eradication of corruption is considered failed or has not succeeded, or at least not yet optimal. Hence the attorney is considered failed, or not yet successful.

Actually, in the handling of corruption crime can also be done by join investigation teams, but for the writing is highlighted only to the Prosecutor. In the criminal law (normative) has been explained that the provisions contained in Article 2 of the Basic Law of the Prosecutor's Office No. 15 of 1961 jo. Law Number 5 Year 1991 jo. Law Number 16 Year 2004 formulates the duty of the Prosecutor's Office in the field of judicial, namely conducting preliminary examination, which includes investigation, further investigation and conducting supervision and coordination of other investigation tools.

At the time when the HIR still applies the criminal procedure law in Indonesia, the investigation is considered part of the prosecution. Such authority makes the public prosecution (prosecutor) as the coordinator of the investigation; even the prosecutor can conduct his own investigation ${ }^{8}$. In the field of investigation, the Prosecutor's Office has a portion as a special criminal investigator covering criminal acts of corruption and not economic crime, although this is temporary, furthermore for the investigation of public crime, the police holds full investigative authority, while the prosecutor is not authorized. ${ }^{9}$

7 Evi Hartanti, Tindak Pidana Korupsi, Sinar Grafika, Jakarta, 2005, Page. 2

8 Marwan Effendy, Kejaksaan Republik Indonesia Posisi dan Fungsinya dari Perspektif Hukum, Gramedia Pustaka Utama, Jakarta, 2005, Page. 145

9 Topo Santoso, Polisi dan Jaksa: Keterpaduan atau Pergulatan, Pusat Studi Peradilan Pidana Indonesia (Centre For Indonesia Criminal Justice Studies), Depok, 2005, Page. 5 
In Law No. 8 of 1981 concerning the Code of Criminal Procedure, hereinafter referred to as Criminal Code, separates explicitly the functions relating to investigation and prosecution, although the Public Prosecutor's Office is still authorized to investigate certain crimes as stated in Article 284 paragraph (2) but its only temporary. When Law No. 2 of 2002 on the Indonesian National Police and Law No. 3 of 2002 on Corruption Eradication Commission (KPK) is in place, the function of investigation and prosecution in handling corruption which previously was the duty and authority of the Attorney Office also changed. Ironically, lawmakers act ambiguously because the resulting legislation product does not have a clear philosophical foundation to overcome the current problems, both the current law (ius constitutum) and the problem of legal implementation (ius contituendum). ${ }^{10}$

The AGO (Attorney General Office) is the body that determines whether a person should be examined by a court or not. The prosecutor also determines whether a suspect will be sentenced or not through the quality of the indictment and the charges made. The important position of prosecutors for law enforcement process, this institution should be filled by people who are professional and have high integrity. The existence of the prosecutor's office in Indonesia is regulated in Law Number 16 Year 2004 regarding the Prosecutor's Office. According to Widodo: ${ }^{11}$ Normatively, the Public Prosecution Service has positioned itself with the issuance of Law No. 16 of 2004 regarding the Attorney General of the Republic of Indonesia which states emphatically that in exercising state power in the field of prosecution and other duties in the law, a prosecutor must be independent and separated from the influence of the power of government and the influence of other powers. To enforce the provisions of Law No. 16, Presidential Decree Number 18 Year 2005 has been stipulated on the Prosecutor Commission of the Republic of

10 Romli Atmasasmita, Reformasi Hukum, Hak Asasi Manusia dan Penegakan Hukum, Mandar Maju, Bandung, 2001, Page. 92

11 Widodo, Pengintegrasian Kebijakan Kriminal terhadap Korupsi di Indonesia Tahun 2008, Artikel IImiah, Fakultas Hukum Universitas Wisnu wardhana Malang 5 Juli 2009.
Indonesia to oversee the conduct of prosecutors and to consider the prosperity and development of the Public Prosecution Service.

In fact, there are many cases of corruption that has not been revealed, this resulted in the public to be pessimistic with the seriousness of the Attorney in revealing various cases of corruption that are happening today. So we have an idea How is the role of the Indonesian procurator in eradicating corruption. And how is the mechanism for handling corruption in the Public Prosecutor's Office in Indonesia.

\section{B. RESEARCH AND DISCUSSION RESULT 1. Existence and Role of Public Affairs in Indonesiai in Combating Corruption}

The Public Prosecution Service of the Republic of Indonesia has a strategic role in eradicating corruption both through preventive and repressive efforts, whether conducted by the Attorney General's Office, the High Prosecutor's Office and the Public Prosecutor's Office. They have shown maximum results both qualitatively and the amount of losses of the State. It also has excelled from other law enforcement agencies.

Prosecutors are officials authorized by law to act as public prosecutors and carry out court decisions that have permanent legal force. In addition, the prosecutor also has the authority to conduct certain criminal investigations. This is intended to accommodate several provisions of the law which authorize the Prosecutor to conduct investigations such as corruption law, human rights court law, and so forth. Meanwhile, the prosecutor is a prosecutor who is authorized to prosecute and enforce the law.

According to Sinarta Sembiring the Chief of State Prosecutor of Purwodadi ${ }^{12}$, he said that the role of Public Prosecutor in corruption case started since the case has not been transferred to court until the execution of court decision. The authority of the public prosecutor before the case is handed over to the courts includes receiving notices, examining case files, making pretenses, making arrests, making indictments,

12 Interview with Sinarta Sembirng as the chief of State Prosecutor Office Purwodadi, at 27 February 2016 
closing matters and bringing cases to court. Subsequent to the role of prosecutors during the court hearing process involves bringing the defendant to trial, reading the indictment, confronting witnesses, preparing evidence, reading out the demand letters, and executing court decisions. Particularly in relation to the handling of corruption, we have always conducted coordination relations with the Police Agency and the Corruption Eradication Commission.

The role of prosecutors in eradicating corruption is so important that a prosecutor is required to be credible and professional in dealing with corruption in solving the problems facing the nation today.

Furthermore, he added that the role of prosecutors can be seen as follows ${ }^{13}$ : Prosecutors as law enforcement officers are also given the authority to conduct investigations on certain criminal acts one of them is a criminal act of corruption. In the handling of criminal acts of corruption as mandated by Law Number 31 Year 1999 , if it is considered there is a corrupt crime that is difficult to prove, then the prosecutor may be involved in the investigation. In addition, it is also affirmed in Law Number 16 Year 2004 regarding the Attorney Office, which determines that the authority of the prosecutor's office to investigate certain criminal acts is intended to accommodate several provisions of the law authorizing the prosecutor's office to conduct investigations, for example, regulation on human rights court, law on corruption crime, and various other laws.

Associated with the authority of the prosecutor as an investigator in the criminal act of corruption, based on the provisions of Article 27 of Law Number 31 Year 1999 concerning the Eradication of Corruption, it is determined that "in the case of a corrupt crime that is difficult to prove it can be formed a joint team under the coordination of the attorney general. It is also affirmed in the provisions of Article 39 which suggest that; the attorney general coordinates and controls the investigation, investigation, and prosecution of the criminal act of corruption committed jointly by persons subject to public court and military court.
Furthermore, in the provision of Article 29, the authority of the investigator is as follows:

1. For the purpose of investigation, prosecution or examination in court, investigation, prosecutor, or judge is authorized to request information to the bank about the circumstances of the suspect or defendant.

2. Requests for information to banks as referred to in paragraph (1) shall be submitted to the Governor of Bank Indonesia in accordance with prevailing laws and regulations.

3. The Governor of Bank Indonesia shall be obliged to fulfill the request as referred to in paragraph (2) within a period of no more than 3 (three) working days, as from the date of receipt of complete request documents.

4. Investigators, public prosecutors, or judges may request the bank to block the savings account of a suspect or defendant suspected of a result of corruption.

5. With the result of the examination of the suspect or defendant there is insufficient evidence, at the request of the investigator, the public prosecutor or judge, the bank in that case also withdraws the blocking.

The provisions mentioned above are conducted to facilitate the process of investigation, prosecution, and corruption criminal investigation. This law regulates the authority of investigators, prosecutors or judges in accordance with the level of handling of cases to be able to directly request information about the financial condition of the accused or defendant to the bank with submit it to the Governor of Bank Indonesia. Furthermore, the authority given to the prosecutor as the investigator as mentioned in the elucidation of Article 26 is the authority of the investigator also includes the authority to conduct wiretapping.

Furthermore, with the same opportunity Askari explained in relation to cooperation in the case of corruption criminal investigation, he stated that ${ }^{14}$ : In the case of alleged corruption of the Prosecutor's Office, always coordinate with related institutions such as police and KPK

14 Interview with Askari as the Chief of ebagai Head of Special Crimes Section of the Public Prosecutor's Office Purwodadi , at 27 February 2016 
(Corruption Eradication Commission) to jointly conduct investigations. As an institution that has the supervisory function of KPK always monitor the progress of corruption handling conducted by the Attorney.

Law Number 16 Year 2004 regarding the Attorney of the Republic of Indonesia provides a strong legal basis for the Prosecutor to carry out investigations and their continuation concerning certain criminal acts, in particular the corruption criminal act. Therefore, the Attorney is highly demanded ability and responsibility to carry out demands and expectations of society. In other words the special criminal field must improve performance by evaluating the execution of the task, solving the problems that arise in all stages of investigation, prosecution until legal effort and execution.

To carry out such a large role, it would require certain qualifications for the prosecutor to carry out the task, especially in relation to law enforcement and / or in the eradication of criminal acts of corruption. So there will be 2 (two) basic problems in this case, namely;

1. Internally

In the institution of the Prosecutor itself that is how to prepare, educate, train and continue learning so as to increase professional acumen in eradicating corruption crime;

\section{Externally}

Although having a big role in the effort of achieving the task of eradicating corruption cannot be done alone by the Attorney, but requires commitment or cooperation with other institutions as well as must be supported from various elements of society.

The duties and authorities of the Public Prosecution Service have been regulated in Article 30 of Law Number 16 Year 2004, which is not only in criminal, civil and state administration but also performs the duties determined by law. It means corruption eradication. Given the wide range of duties and authorities, it is impossible to perform optimally without the commitment and cooperation of related institutions in the integrity criminal justice system with a proportional, independent and non-interdependent context in the sense of their respective functions, organized harmoniously toward certainty in law, especially in dealing with corruption cases that have recently shown a tendency to increase in quality and quantity.

The important role played by the AGO is inseparable from the manifestation of state representation in protecting its citizens. For this reason, the aspect of respect and adherence to universal legal principles in performing the task becomes a very decisive element.

\section{Mechanism of Corruption Crime Handling in Public Prosecutor's Office in Indonesia}

\section{Investigation}

Investigators in the criminal act of corruption were first handled by the prosecutor of the Attorney as well as by the police investigators. In a special criminal act, the prosecutor acts as an investigator. The legal basis which authorizes the investigation of corruption to the Attorney is Article 30 paragraph (1) sub-paragraph d of Law Number 16 Year 2004 regarding the Attorney General of the Republic of Indonesia which reads; "In the criminal field, the Attorney General has the duty and authority to conduct investigations on certain crimes"

Based on the article, the criminal act of corruption is a special crime in the sense that corruption has special provisions of criminal procedure. Thus the Prosecutor's Office has the authority to conduct an investigation. Criminal offenses containing provisions of certain offenses are called "special criminal acts". The criminal act of corruption based on Law Number 20 Year 2001 regarding the Amendment to Law Number 31 Year 1999 concerning the Eradication of Corruption contains "special provisions of criminal procedure", there are;

a. The suspect is obliged to provide information about all known corporate property (Article 28)

b. The defendant has the right to prove his innocence (Article 37)

c. In the event that the defendant has been legally invoked and is not present in court for no valid reason, the case may be examined and terminated without his presence (Art. 38). 
The official explanation of the above article is intended because corruption is difficult to prove. There are corruption in the field of Banking, Taxation, Capital Market, Trade, Industry, Commodity Futures, Monetary and Finance fields;

a. Sectoral;

b. Performed using advanced technology;

c. Conducted suspect or defendant having status as State Operator as stated in Law Number 28 Year 1999 concerning State Organizer that is clean and free from Corruption, Collusion and Nepotism;

In addition to the above things, for the sake of law and the smooth eradication of corruption, the Attorney Office in handling a case of corruption should be penetrated by "Investigation Order" to the Kapolres and/or Kapolda, in order not to overlap.

Further, it is different from the general criminal offense that initial data is obtained from reports or complaints, but the criminal act of corruption comes from;

a. Vice President;

b. Minister / Irjen / Irwailprop / Irwilkop;

c. Intelligence apparatus;

d. DPR (which is the result of BPK audit)

In addition, based on the above points, according to Sinarta Sembiring, suggests about other sources of information can be like ${ }^{15}$; Allegations of corruption can be sourced from various sources, such as on the basis of reports of the community both personally and on reports from non-governmental organizations (NGOs). However, reports originating from the public, both personally and on the basis of reports from non-governmental organizations (NGOs) are usually incomplete and supported by preliminary evidence to support allegations of corruption.

After the initial data, an Investigative Order is issued, to determine whether or not a corruption is taking place, with sufficient initial evidence to be obtained. However, with the issuance of an Investigation Order, many people are suspicious that corruption has been committed. It is a mistake because sometimes there is insufficient initial evidence. If no sufficient initial evidence is

15 Interview with Sinarta Sembirng as the chief of State Prosecutor Office Purwodadi, at 27 February 2016 obtained, then the investigation is not continued. Where sufficient preliminary evidence is found, investigations are upgraded to the investigation stage, and subsequently issued an Investigation Order.

\section{Investigation}

The investigation is a very important role in determining whether there is a crime or not. Therefore, the examination is carried out before investigation, as an action that precedes the investigation in advance there should be a suspicion or knowledge about the occurrence of a criminal offense. The allegations of the occurrence of this crime can be obtained from several sources namely;
a. Caught;
b. Report;
c. Complaint;
d. Self-identified;

The investigating officer who expands the tasks in the warrant immediately makes a "Investigation Plan" (Rendik), by understanding the outcome of the investigation and the rules relating to the criminal act of corruption he is investigating, so as to be able to determine the deviations that have occurred and the evidence supports such a deviation so that the operable mode can be determined.

Investigators of corruption will begin investigating after obtaining an Inquiry Letter from the Chief Prosecutor of the State if the investigator is the prosecutor at the State Attorney.

Similarly, Sinarta Sembirng also added that ${ }^{16}$ : The report on corruption, which has a strong indication of corruption, will be followed up by forming a team consisting of several prosecutors with varying amounts depending on the size of cases and the availability of prosecutors. In practice, it usually consists of 3 to 5 prosecutors. After the team is formed, with the coordination of the team leader, discuss the alleged criminal act of corruption with the division of their respective duties, including preparing the renlid plan and the time schedule of the summoning required information.

The reason of forming this team is to facilitate and to accelerate the investigation and with this team will complement each other between

$16 \quad$ Ibid 
the prosecutors. If one of the prosecutors has weaknesses in other cases, it can be covered with the advantages of other prosecutors. Investigation begins after the commencement of a criminal offense to obtain information about;

a. What crime is being committed;

b. When the offense was committed;

c. With what crime was committed;

d. How the crime was committed;

e. Why the act was done;

The thing that the investigator must pay attention to initiate an investigation is to inform the commencement of the investigation to the prosecutor. If the investigation of a criminal act of corruption is committed by the police, this notice is mandatory, in the absence of two investigators, namely from the Public Prosecution Service or from the police in certain offenses, especially corruption.

Whereas in the criminal act of corruption in which the investigator is prosecutor, then the notice on the start of the investigation in practice is not done, because the prosecutor will be investigator as a public prosecutor, so that the public prosecutor is clearly aware of the commencement of the investigation. In carrying out its duties, the investigator in a criminal act of corruption, the prosecutor has the authority set forth in Article 7 paragraph (1) of the Criminal Procedure Code which states; "Investigator as referred to in Article 6 paragraph (1) letter a because the obligation has authority";

a. Receive a report or complaint from someone about a crime;

b. Take the first action at the scene;

c. Trigger a suspect and check the suspect's identity;

d. Conduct arrest, detention, search and seizure;

e. Check and confiscating mail;

f. Take fingerprints and photograph someone;

g. Call people to be heard and checked as defendants or witnesses;

h. Bring the necessary expert in connection with the examination of the case;

i. Conduct termination of investigation;

j. Carry out other actions under responsible law;
Based on several authorities above, the interesting things that need to know by ordinary people, namely;

a. The summon of a witness or suspect using a summons containing the called identity, ie name, occupation of address, time and place of call, calling status, article being construed, and mentioning the name of the investigator summoning, signing by the investigator and by telephone who can be contacted;

b. In the process of investigation, the examination of the suspect is done after the examination of the witness is done, it is intended to get the complete information on a criminal act of corruption;

c. Investigative action in the form of restraint of suspect or defendant's freedom if there is sufficient evidence for the time being for the purpose of investigation or prosecution and or judicial (Article 1 point 20);

d. Regarding the search is divided into 2 (two) kinds, namely houses of residence and searches of bodies and or clothing, both of which are regulated in KUHAP;

e. The investigator carrying out the search action should bring along and pay attention to the assignment letter. The investigator conducting the search should bring and show his or her assignment to the occupant or the owner of the house to be searched;

f. After a report on the progress of the investigation to obtain approval from the leadership, will be filed in the form of a case file. Then submitted to the field of prosecution of special crime and will examine the case file, whether the file of the case has fulfilled formal and material requirements;

Furthermore, it is important to know that the role of prosecutors in corruption is different from its role in ordinary crime. Corruption is special, whereas ordinary crime is general.

\section{Prosecution}

After the public prosecution receives a case file from the investigator, and according to the prosecutor, the file is complete and prosecution can 
be made, then the prosecutor may immediately file an indictment as soon as possible. The definition of prosecution can be seen in Article 1 point 7 of the Criminal Procedure Code.

In Article 13 of the Criminal Procedure Code, the prosecutor formulates that the prosecutor is a prosecutor who is authorized to prosecute. The authority of the public prosecutor under Article 14 of the Criminal Procedure Code is;

a. Receiving and examining investigationcase files from investigators or investigators;

b. Conducting a pre-requisite when there is a lack of investigation with respect to Article 110 paragraphs (3) and (4), by providing guidance in order to improve the investigation of the investigator;

c. Providing for an extension of detention, incarceration or continued detention and/ or changing the status of detainees after the case has been delegated by the investigator;

d. Making an indictment;

e. Submitting case to court;

f. Submitting notice to the defendant concerning the provision and time of court proceedings accompanied by summons, both to the defendant and to the witness to come to a predetermined session;

g. Prosecuting;

h. Closing the case for the sake of the law;

i. Conducting a case in the public interest;

j. Carrying out other actions within the scope of duties and responsibilities of the public prosecutor by law;

k. Conducting judges' determination;

At the stage of prosecution, in general, it has been appointed Public Prosecutor and Substitute Prosecutor. It is often the case that the Public Prosecutor with the Substitute Prosecutor, not integrated, should be prevented. The Public Prosecutor with the Substitute Prosecutor must fill each other so that negligence in the handling of the case can be prevented.

The Public Prosecutor along with the Substitute Prosecutor conducted a thorough research, especially against all elements of the crime that will be charged, whether it has been supported evidence tools, as well as formal terms applicable. If in his opinion there is still a shortage, it can be equipped itself or returned to the investigator to be completed.

If after the implementation of the refinement there are elements that are not proven or indicate that the suspect cannot be in blame then the Letter of Decision of Prosecution Termination or commonly called (SKPP) is issued. Lately, there are problems about the revocation of SP3/SKPP (Letter of Decision of Prosecution Termination) because it is not regulated in the Criminal Code, so that some argue that SKPP cannot be revoked on the grounds that the revocation is not regulated in the Criminal Code. The reason is not strong enough because both SKPP has not been the result of trial examination so that the suspect's acts have not been tried.

In relation to his position as Public Prosecutor in a criminal case, Askari argues that; ${ }^{17}$ The Prosecutor has never or may not meet and deal with the suspect until the court hearing. Since in all cases done by persecutor all depends heavily on what is in the file of his case received from the investigator. Thus, if there is a mistake in the examination that is not done by him, the prosecutor still has to take responsibility for it, this is to maintain the transparency, independency, and credible of a public prosecutor as a state lawyer.

In preparing the prosecution, the Prosecutor after receiving the completed case file from the investigator, immediately determines whether the file of the case is eligible for or not to be transferred to the court. There are two possibilities that the Prosecutor can make against the file of the case, which is to prosecute or stop the prosecution.

Prosecution in this case can be done if the case file submitted by the investigator is considered complete and the case can be prosecuted by the prosecutor. The prosecutor then makes an indictment. Termination of prosecution may occur, in the case of the Prosecutor arguing that;

a. Not enough evidence in the case;

b. The incident turned out not to be a crime;

c. Case closed by law;

17 Interview with Askari as the Chief of ebagai Head of Special Crimes Section of the Public Prosecutor's Office Purwodadi , at 27 February 2016 
The termination of this prosecution shall be made by the Public Prosecutor by drawing a Letter of Determination of Termination of Prosecution (SP3). In the event that the prosecution is terminated, the suspect in custody must be released if there is a new reason for the public prosecution of the investigator, deriving from the testimony of the witness, the item or the clue, and then it is not possible to prosecute.

Although the acts of the suspect are not supported by sufficient evidence or the act cannot be blamed on him, but the Public Prosecutor does not issue SKPP but it is brought before the court with the intention of being freed. Free prosecution by the Public Prosecutor is often misinterpreted. The argument is unreasonable because the prosecutor filed his lawsuit based on trial hearings in order to uphold justice based on the truth. The free demands put forward by the Public Prosecutor are unacceptable to the public because the society has tended to be that a person accused of corruption is right. Apart from that, the people of revenge against corruption that assume have harmed the society and the state.

\section{Conclusion}

The existence and role of Purwodadi State Prosecutor Institution in eradicating corruption begins when the case has not been transferred to the Court until the execution of court decision. But in the criminal act of corruption, the Prosecutor's Office has the authority as a public prosecutor as well as an investigator. The authority of the prosecutor as a special criminal investigator shall be regulated by Law Number 16 Year 2004 regarding the Attorney of the Republic of Indonesia in Article 30 paragraph (1) letter d. In addition, in its role against the eradication of corruption, the Prosecutor's Office always carries out coordination relations with the police agencies and the Corruption Eradication Commission.

The mechanism of handling corruption in the Public Prosecutor's Office in Indonesia is through several procedures that have been specified in the law include; an investigation which is a series of investigative actions to seek and find an alleged criminal act. An investigation which is an investigator's action in respect of and in the manner prescribed by law to seek and collect evidence with such evidence may make the light of the offense and to find the suspect. As well as prosecution where the prosecutor general to delegate criminal cases to the appropriate state court in terms of the manner prescribed in the law.

\section{BIBLIOGRAPHY}

Andi Hamzah, 2003, Korupsi di Indonesia Masalah dan Pemecahannya, Gramedia Pustaka Utama, Jakarta.

2005, Pemberantasan Korupsi Melalui Hukum Pidana Nasional dan Internasional, Raja Grafindo Persada, Jakarta.

A. Ridwan Halim, 1986, Hukum Pidana dalam Tanya Jawab, Ghalia Indonesia, Cetakan Ketiga, Jakarta.

Barda Nawawi Arief, 1998, Beberapa Aspek Kebijakan Penegakan dan Pengembangan Hukum Pidana, Citra Aditya Bakti, Bandung.

2007, Masalah Penegakan Hukum dan Kebijakan Hukum Pidana dalam Penanggulangan Kejahatan, Kencana Prenada Media Group, Jakarta.

Cholid Narbuko dan abu Achmadi, 2001, Metodologi Penelitian, Bumi Aksara, Jakarta

Edy Yunara, 2005, Korupsi dan Pertanggungjawaban Pidana Korupsi, Citra Aditya Bakti, Bandung.

Efi Laila Kholis, 2010, Pembayaran Uang Pengganti dalam Perkara Korupsi, Solusi Publishing, Jakarta. 
Evi Hartanti, 2005, Tindak Pidana Korupsi, Sinar Grafika, Jakarta.

Ermansjah Djaja, 2008, Memberantas Korupsi Bersama KPK, Sinar Offset, Jakarta.

Firman Wijaya, 2008, Peradilan Korupsi Teori dan Praktik, Penaku dan Maharini, Jakarta.

Hermien Hadiati Koeswadji, 1994, Korupsi di Indonesia, dari Delik Jabatan Ke Tindak Pidana Korupsi, Citra Aditya Bakti, Bandung.

Jeremy Pope, 2003, Strategi Memberantas Korupsi, Penerjemah; Masri Maris, Yayasan Obor Indonesia, Jakarta.

Lilik Mulyadi, 2007, Tindak Pidana Korupsi di Indonesia; Normatif, Teoritis, Praktik dan Masalahnya, Alumni, Bandung.

Muhammad Ekaputra dan Abdul Kahir, 2010, Sistem Pidana di Dalam KUHP dan Pengaturannya Menurut Konsep KUHP Baru, Usu Press, Medan.

Muhari Agus Santoso, 2002, Paradigma Baru Hukum Pidana, Averroes Press, Jakarta.

Mardjono Reksodiputro, 2002, Korupsi dalam Sistem Hukum. Mencari Uang Rakyta: 16 Kajian Korupsi di Indonesia. Ed. Hamid Basyaib, Richard Holloway, dan Nono Anwar Makarim. Aksara Foundation, Jakarta.

Marwan Effendy, 2005, Kejaksaan Republik Indonesia Posisi dan Fungsinya dari Perspektif Hukum, Gramedia Pustaka Utama, Jakarta.

2012, Kapita Selekta Hukum Pidana "Perkembangan dan Isu-isu Aktual dalam Kejahatan Finansial dan Korupsi”, Cetakan Pertama, Referensi, Jakarta.

Martiman Prodjohamidjojo, 2001, Penerapan Pembuktian Terbalik dalam Delik Korupsi (UU Nomor. 31 Tahun 1999), Mandar Maju, Bandung.

Mochtar Lubis \& James C. Scott, 1995, Bunga Rampai Korupsi, LP3ES, Jakarta.

Romli Atmasasmita, 2001, Reformasi Hukum, Hak Asasi Manusia dan Penegakan Hukum, Mandar Maju, Bandung.

, 2006, Ratifikasi Konvensi Perserikatan Bangsa-Bangsa Menentang Korupsi dan Implikasinya terhadap Sistem Hukum Pidana Indonesia, Paper, Jakarta.

, 2004, Sekitar Masalah Korupsi Aspek Nasional dan Aspek Internasionall, Mandar Maju, Bandung.

Soerjono Soekanto, 1997, Sosiologi Suatu Pengantar, Yayasan Penerbit UI, Cetakan Ke IV, Jakarta.

, 1990, Ringkasan Meteodologi Penelitian Hukum Empiris, Indonesia Hillco,

Jakarta.

dan Sri Mumadji, 2001, Penelitian Hukum Normatif Suatu Tinjauan Singkat, Raja Grafindo Persada, Jakarta.

Sugono, 2008, Metode Penelitian Kuantitatif Kualitatif dan R \& D, Alfabeta, Bandung.

Sunaryati Hartono, 2004, Pengantar Penelitian Hukum, UI Press, Jakarta.

Sri Sumarwani, 2012, Sebuah Seri Metode Penelitian Hukum, UNDIP Press, Semarang.

Sunaryati Hartono, 2002, Penelitian Hukum di Indonesia Pada Akhir Abad ke-20, Alumni, Bandung.

Syed Hussein Alatas, 2012, Sosiologi Korupsi: sebuah Penjelajahan dengan Data Kontermporer, Cetakan Ketiga, LP3ES, Jakarta. 
Yesmil Anwar dan Adang, 2009, Sistem Peradilan Pidana, Konsep, Komponen \& Pelaksanaannya dalam Penegakan Hukum di Indonesia, Widya Padjadjaran, Bandung.

Topo Santoso, 2005, Polisi dan Jaksa: Keterpaduan atau Pergulatan, Pusat Studi Peradilan Pidana Indonesia (Centre For Indonesia Criminal Justice Studies), Depok.

Widodo, 2009, Pengintegrasian Kebijakan Kriminal terhadap Korupsi di Indonesia Tahun 2008, Artikel Ilmiah, Fakultas Hukum Universitas Wisnuwardhana Malang.

Undang-undang Dasar Negara Republik Indonesia year 1945.

Undang-undang Number 8 year 1981 about Kitab Undang-undang Hukum Acara Pidana.

Undang-undang Number 20 Year 2001 about Pemberantasan Tindak Pidana Korupsi

Undang-undang Number 16 Year 2004 about Kejaksaan Republik Indonesia

Undang-undang Number 48 Year 2009 about pengadilan Tindak Pidana Korupsi.

Undang-Undang Republik Indonesia Number 28 Year 1999 about Penyelenggara negara Yang bersih dan Bebas dari Korupsi, Kolusi dan Nepotisme.

Undang-Undang Republik Indonesia Number 31 Year 1999 about Pemberantasan Tindak Pidana Korupsi.

Undang-Undang Republik Indonesia Number 30 Year 2002 about Komisi Pemberantasan Tindak Pidana Korupsi.

Peraturan Pemerintah pengganti Undang-Undang Republik Indonesia Number 4 Year 2009 tentang Perubahan atas Undang-Undang Republik Indonesia Nomor 30 Tahun 2002 tentang Komisi Pemberantasan Tindak Pidana Korupsi.

Peraturan Penguasa Militer Nomor PRT/PM/011/1957 about Penyitaan dan Perampasan Harta Benda 